\title{
IMPACT OF ENTERPRISE RESOURCE PLANNING (ERP) ON INTERNAL AUDIT FUNCTIONS
}

\author{
Reni Nilasari \\ Faculty of Economics and Business, Airlangga University, No. 4-6 Airlangga Sreet, Surabaya 60115, Indonesia
}

\begin{abstract}
The purpose of this paper is to find out why internal auditors must have the skills and abilities in the field of technology in carrying out their activities in the company on the basis of an ERP system. An ERP system is a tool that integrates all company functions in a more accurate system. Design / Methodology / Approach: Library research by emphasizing how the challenges of current internal auditors in facing technological advances (ERP) in the company. Findings: That ERP has a significant impact on the Internal Auditor. Therefore it is necessary to improve the skills and abilities of the Auditor in using technology so that they can develop their HR through training or training related to the ERP system. Originality: This paper tries to emphasize why internal auditors must have the skills and abilities in the field of technology and how the challenges faced by internal auditors change.
\end{abstract}

Keywords: enterprise resource planning (erp), internal auditor function.

DOI: $10.7176 /$ RJFA/10-9-05

Publication date:May $31^{\text {st }} 2019$

\section{Introduction}

Indonesia experienced a very fast and very competitive economic change, resulting in turbelence in terms of technology, regulation and market structure. In facing environmental changes like this we can see from various fields that can innovate and take strategic steps, especially in securing sustainability and competitiveness. Judging from the economic development the most influential thing is technology. Today we can see around us that all aspects of community activities cannot be separated from technology. We can also see the use of technology in company activities. Currently companies in Indonesia such as PT. Telkomsel, PT. Semen Gresik, Garuda Indonesia, PT. Belfoods, PT, HM Sampoerna, PT. Indofood, PT. PLN (Persero), PT. Pertamina, PT. Astra Agro Lestari, PT. Jasa Marga (Persero) and many others who use technology as an alternative in increasing their business activities. With the implementation of ERP in each company as a form of internal control that is considered more accurate and relevant.

A good accounting information system can be supported by various media that can help one of them at this time, namely enterprise resource planning (ERP). In that sense the enterprise resource planning system (ERP) is a software system in the form of a business application that integrates all organizational functions, including human resources, finance, manufacturing, sales, and distribution (Madani, 2015). ERP implementation can improve performance and quality performance innovations that have a direct impact on improving company work, especially in improving the accuracy of information between departments within the company, faster customer response, and appropriate decision making and better use of resources so that it impacts on income company. Data integration in ERP is done with a single data entry, where a department has a function that can enter data, so that this data can be used by other functions within the company. ERP is one way to manage company resources with the use of information technology. ERP is equipped with hardware and software to coordinate and integrate information data in the business area to produce fast decision making because it provides rapid financial analysis and reports. This technology is one of the ideal solutions for companies that have grown rapidly and have many advantages that help improve company performance.

ERP systems provide new challenges for internal control which result in changes to the structure and practice of internal audit functions. The internal audit function is to carry out activities related to the company. Internal audit activities include environmental control, risk assessment, control, information and communication, and supervision (COSO, 2013). The Committee of Sponsoring Organization (COSO) provides an explanation that an internal control system is the basis for operational and accounting processes in a company or business activities to be more effective. The implementation of effective internal control is a fundamental principle of internal audit. The implementation of an ERP system has an impact on changes in the company and its information systems. With integrated controls it is possible for internal audits to maintain effective control over operations that 
guarantee information on all reliable transactions that are consistent with the company's goals. Thus the internal audit function remains the same, but the difference is that the control mechanism and control procedures change. The detailed and complete functions of internal auditors can show that overall the activities of internal auditors must be applied thoroughly to all company activities, so as not to be limited to accounting records. The functions of internal auditors include activities including:

1. Examination and assessment of the effectiveness of the internal control structure and encourage the use of a more effective internal control structure by using the right costs.

2. Determine how far the implementation of top management policies is carried out.

3. Determine where the company's wealth is accounted for and protected from a variety of risks and losses.

4. Determine the reliability of information produced by various parts of the company.

5. Provide recommendations for improvements to company activities.

So the function of internal auditors is not limited to routine checks for errors regarding the accuracy and correctness of accounting records, but conducts an evaluation and assessment of various elements of the company's operations. In a previous study conducted Madani (2015) which provides an understanding of a framework that describes the relationship of ERP systems and internal auditors. That ERP provides new challenges for the internal audit function. Internal auditors must have the ability in the field of technology, this is very important when conducting the audit process. Elbardan, Ali, and Ghoneim (2015) changes in internal audit function as a form of response to the ERP system. Internal audit is expected to be able to expand their skills to work more effectively and efficiently in the ERP system work environment. This means that internal audit functions no longer carry out manual activities in the presence of an ERP system. Internal auditors must be able to compete and improve their knowledge in the field of technology to develop devices from this ERP system. The purpose of this study is to provide an understanding that the functions of internal auditors currently not only include activities in control, risk assessment, information and communication, and supervision, but also have more important functions, namely the improvement or development of an ERP system in achieving company goals. So it is necessary to increase the taking of internal auditors so that they are no longer left behind by other parties or competitors. This research is a development of previous research conducted (Madani, 2015), for this study more emphasis on why internal audits need to add expertise or skills, knowledge, abilities, and experience that must be owned by internal audits to carry out their roles and functions within the company ERP based.

Based on the explanation above, the research question is why internal auditors need to add expertise, knowledge, ability and experience in running ERP-based companies?

\section{Literature Review}

\subsection{Enterprise Resource Planning (ERP) Technology}

Environmental changes in the company require using more modern technology. ERP is the latest technology that can integrate all data related to the company. Wicaksono, Mulyo, and Riantono (2015) ERP is an application of enterprise-based information that enables the integration of data contained in all units in the organization so that this enables business organizations to make decisions accurately and quickly. Kristianti and Achjari (2018) ERP is a data integration system that can increase employee productivity and can improve the management of accounts receivable and inventory. ERP has a positive impact on the component of performance quantity of work (number of jobs completed in a certain period), quality of work (quality of work in accordance with predetermined standards), job knowledge (knowledge of work and what things are the responsibility the answer), creativeness (creativity to create solutions to problems that arise in the work), dependability (awareness of the completion of the work done), personal qualities (quality of a worker that includes personality, leadership, attitudes in everyday life and integrity).

\subsection{Internal Auditor Function}

Internal audit is a process carried out by the board of directors, management, and other personnel of an organization designed to provide adequate confidence in achieving effectiveness and efficiency, reliability of financial statements and compliance with applicable laws and regulations (COSO, 2013). The purpose of internal audit is to ensure that organizations or companies can carry out their duties and have good responsibilities, so that each member works together. The internal auditor's functions are very detailed and complete for internal aduit activities that can be applied thoroughly to the company's activities. To carry out its activities, internal auditors have activities to conduct checks and assessments on the effectiveness of the internal control structure and encourage the use of an effective internal control structure with minimum costs. 


\section{Research Methods}

The type of this research is library research, which is research using library data collection methods or research whose object of research is explored through various library information such as books, scientific journals and documents. Library research is a critical review of the knowledge, ideas, or findings contained in the body of literature. Focus library research to find various theories, laws, arguments, principles or ideas that are used to analyze and solve research questions formulated.

\section{Results and Discussion}

\subsection{Application of Enterprise Resour Planning (ERP) Systems for company effectiveness.}

As explained earlier, ERP is a system that integrates all organizational functions, including human resources, finance, manufacturing, sales, and distribution (Madani, 2015). So that new challenges arise for internal control which results in internal auditor functions. This ERP can eliminate human functions with data flow processes that can improve security and more accurate information. The purpose of this ERP system is to integrate the company's overall business. ERP has a role including:

1) To automate and integrate business processes

2) To share a common database and business practices through the enterprise

3) To produce real-time information

4) To integrate transaction and planning processes.

Kanellou et all (2012) the implementation of enterprise systems can improve monitoring of corporate transactions continuously. Wicaksono, Mulyo, and Riantono (2015) ERP concepts can improve and strengthen the effectiveness of existing resources in the company. In the implementation of ERP management, the commitment must be that this ERP is important so that training is needed so that the system runs properly. In additionSelain itu (Bae and Ashcroft, 2004) technology has an important role in the business environment. Where currently many companies are very dependent on computers and software in providing accurate information effectively in managing their business. The successful and large-scale technologies is the company's resource planning system (ERP) in achieving company goals.

1. The important thing about ERP is to make it easier for companies or organizations doing business so that the information in the company is more accurate and integrated. ERP implementation is the technological sophistication of today which is important for the company.

2. As we know, when management's strategic decision making needs actual data from internal companies that can be obtained quickly, precisely and efficiently. Then technology is needed that can integrate parts of the company. ERP systems can help the overall management needs of the business organization so that the information obtained is more relevant for decision making.

4.2 Changes in the Role of Internal Auditors in Facing ERP Implementation.

Sophistication of the ERP system has an impact on the functions of internal auditors (Elbardan, Ali and Ghoneim, 2015) and (Madani, 2015) where these internal auditors no longer run or control company activities manually with this ERP system all data flow systems can be integrated so that they do not easy errors or cheating. For this reason, the function of the internal auditor is emphasized to take a role in the advancement of technology so that it can develop the existing system. In achieving the company's objectives with the implementation of the ERP system it is expected that internal auditors have the expertise, knowledge, abilities and experience in the field of technology. To master the usual technology companies hold training for their employees so that they have IT expertise.

The results of previous studies (Kanellou and Spathis, 2012) show that the presence of IT auditors is more important, while financial auditors are expected to be able to improve their skills in order to conduct more effective audits. Internal auditors are the most important factor to control the life cycle and implementation of Enterprise Systems. When internal auditors are faced with technological advancements, they are expected to be able to have the skills and be able to run the system. Because this is very important for sustainability in achieving company goals. How do these internal auditors have expertise and capabilities in the field of technology. This can be obtained by the training and training held by the company to provide expertise and capabilities in the field of technology. In this section the way to analyze the skills and capabilities that internal auditors must have is to study the software from ERP and how it works so that it can help companies improve management of operations more efficiently (Bae and Ashcroft, 2004). ).

In analyzing the expertise and capabilities of internal auditors according to (Kanellou et al. 2012), others: 
1) Having new audit tools and modern techniques needed

2) Sustainability of audit techniques is increasing

3) EAM and MCL are the basic methods to audit an enterprise system environment

4) Auditors must be able and know how to use ERP tools, techniques and methodologies

5) In enterprise systems substantive testing and control tests must complement each other.

The implementation of ERP affects the system that exists in the company and the audit process. If auditors do not have the skills and ability to use technology, they can get rid of or threaten their work and be replaced with other competitors who are more competent in the field of technology. So with this, why do you need to improve skills for internal auditors. This was supported in the study (Musa 2008) that the internal audit must improve knowledge and skills in the field of technology. It is important for auditors to have knowledge and technology skills in conducting the process of planning, directing, monitoring and reviewing the work carried out.

\section{Conclusion}

Changes in the role of internal auditors are the impact of the application of enterprise resourch planning (ERP) systems which consequently forces internal auditors to have the skills and abilities to use the ERP system. Thus the function of the internal auditor can follow technological developments to maintain, control and evaluate the business processes of the company. This ERP system can strategically encourage companies and can replace company data in a system that is more integrated with more accurate information so that it can increase the effectiveness of the company.

\section{Reference}

Bae, B. And Ashcroft, P. (2004) 'Implementation Of Erp Systems : Accounting And Auditing Implications', Information Systems Audit And Control Association, 5.

Coso (2013) Coso Internal Control - Integrated Framework ( 2013 ).

Elbardan, H., Ali, M. And Ghoneim, A. (2015) 'The Dilemma Of Internal Audit Function Adaptation The Impact Of Erp And Corporate Governance', Journal Of Enterprise Information Management, 28(1), Pp. 93-106. Doi: 10.1108/Jeim-10-2013-0074.

Kanellou, A. And Spathis, C. (2012) 'Auditing In Enterprise System Environment: A Synthesis', Journal Of Enterprise Information Management, 24(6), Pp. 494-519. Doi: 10.1108/17410391111166549.

Kristianti, C. E. And Achjari, D. (2018) 'Application Of Enterprise Resource Planning Systems: The Impact On Corporate Financial Performance', Jurnal Akuntansi \& Auditing Indonesia, 21(1), Pp. 1-11.

Madani, H. H. (2015) 'The Role Of Internal Auditors In Erp-Based Organizations', Journal Of Accounting \& Organizational Change, 5(4), Pp. 514-526. Doi: 10.1108/18325910910994702.

Wicaksono, A., Mulyo, H. H. And Riantono, I. E. (2015) 'Enterprise Resource Planning (Erp): Impact In Education, Accountant And Auditor Profession’, Binus Busine Ss Review, 6(9), Pp. 25-34. 